\title{
ORIGINAL CONTRIBUTION \\ The Development of a Marketing Tourism Model Toward Intention to Visit and Decision to Visit in Leading Tourism Object
}

\author{
Mutia Tri Satya ${ }^{1 *}$, Yuyus Yudistria ${ }^{2}$, Muhammad Asdar ${ }^{3}$, Andi Abdul Razak Munir ${ }^{4}$ \\ 1,2 STIE Ekuitas, The College of Economics, Finance, Banking and Entrepreneurship, Bandung, Indonesia \\ ${ }^{3,4}$ Hasanuddin University, Makassar, Indonesia
}

\begin{abstract}
The purpose of this study is to develop a model of marketing tourism at the leading tourism object in Bandung and Soppeng, Indonesia. This model will be linked to its influence with the intention to visit and the decision to visit. At the present time, Bandung and Soppeng strives to become one of the tourist destinations both in Indonesia and in the world. Improvement of facilities and infrastructure facilities is carried out by the government to provide comfort for tourists who are increasing in number to visit. Data is collected through questionnaires, interviews, observation and secondary data. Simple random sampling is used for distributing questionnaires to respondents. Respondents in this study were 100 tourists from city of Bandung, as well as 100 respondents who were tourists in Soppeng Regency. Data processing techniques use Structural Equation Modeling (SEM) to conduct analysis among several dependent and independent variables directly. The results of this study analyze the dimensions of each variable marketing tourism (economy, social, culture, information technology, environment), intention to visit (interest, searching information, preferences) and decision to visit (attitude, memory, perception, need). The dimensions of each variable showed the magnitude of the effect. Bandung a value of $6.62 \%$ for the construct of decision to visit, value is also found in intention to visit which is influenced by tourism marketing of 5.74\%. Soppeng values for the decision to visit construct $7.33 \%$, and value is also found in intention to visit which is influenced by tourism marketing of $7.09 \%$. which means that the influence between significant constructs. The model developed in current study is expected to be applicable in terms of tourism development.
\end{abstract}

Index Terms - Marketing Tourism, Intention to Visit, Decision to Visit.

Received: 11 March 2019; Accepted: 21 May 2019; Published: 27 June 2019

\section{Introduction}

Bandung and Soppeng are regions that have considerable tourism potential. This can be seen from the many tourist destinations available in both regions. If the potential is able to be utilized and managed properly, it can be a large source of regional income.

The following data shows the number of non-starred hotels, restaurants and tourist attractions in Soppeng Regency from 2013-2014:

Table I

Number of non-star hotels and restaurants in Soppeng Regency

\begin{tabular}{lll}
\hline Year & Number of Non starred hotels & Number of Restaurants \\
\hline 2013 & 17 & 31 \\
2014 & 20 & 32 \\
2015 & 22 & 34 \\
2016 & 23 & 34 \\
2017 & 16 & 34 \\
\hline
\end{tabular}

Source: Soppeng District Culture and Tourism Office

Soppeng Regency itself has many interesting tourist destinations to visit and become a leading destination in the Soppeng Regency area.

\footnotetext{
*Email: mutia.satya@gmail.com
}

Here are some of the tourist areas in Soppeng Regency and recorded in the Soppeng Regency Book in Angkat 2018, namely:

Table II

Tourist attractions in Soppeng Regency and its types

\begin{tabular}{ll}
\hline Tourist/Recreation place & Kind \\
\hline Kalong & Animal \\
Vila Yuliana & Historical Tourism \\
Pemandian Alam (Natural Baths ) Ompo & Natural Tourism \\
Pemandian Air Panas (Hot water bath) Lejja & Natural Tourism \\
Pemandian Alam (Natural Baths ) Citta & Natural Tourism \\
Goa (Cave) Codong Citta & Historical Tourism \\
Kawasan Wisata (Tourist Area) Lereng Hijau Bulu Dua & Natural Tourism \\
Kompleks Istana Datu & Historical Tourism \\
Makam (Tomb ) Jera Lompoe & Historical Tourism \\
Watu & Historical Tourism \\
Sutra Alam & Agro tourism \\
Rumah Adat (Custom home ) Sao Mario & Culture Tourism \\
\hline Source: Soppeng District Culture and Tourism Office &
\end{tabular}

The number of tourists visiting Soppeng in 2017 was 224,018. Compared to 2016, there were only around 218,387 tourists visiting Soppeng 
(Tribun-Timur, 2017) This is due to the incessant promotion carried out including through online media.

The city of Bandung also has a variety of potential tourist destinations with a relatively high level of visits, both local and foreign tourists and even foreign tourists. Based on data from Bandung City in Angkta 2018, the number of starred hotels is 127 hotels, and non-starred hotels are 218. Tourism in the city of Bandung consists of various tourism businesses, such as historic buildings, museums and so on. Besides that it is also supported by restaurants, restaurants, and cafes. In 2017 there were 396 hotels, 372 restaurants and 14 cafes and 13 bars.

The number of tourists visiting the city of Bandung is quite a lot. Moreover, the visits made were not only from domestic tourists but also from foreign tourists. The following is data from tourists visiting Bandung:

Table III

Number of tourist visits to the city of Bandung

\begin{tabular}{llll}
\hline Year & Foreign Tourists & Domestic & Tourist Number \\
\hline 2013 & 176.432 & 5.388 .292 & 5.564 .724 \\
2014 & 180.143 & 5.627 .421 & 5.807 .564 \\
2015 & 183.932 & 5.877 .162 & 6.061 .094 \\
2016 & 173.036 & 4.827 .589 & 5.000 .625 \\
\hline
\end{tabular}

Tourism Marketing is an important foundation for building a good tourist destination. This will affect the increase in visits to tourism destinations both in the Soppeng and Bandung regencies.

Based on the description above, this study aims to develop a research model related to marketing tourism, intention to visit, and the decision to visit with the object of research is the city of Bandung and Soppeng.

\section{Literature Review}

Tourism marketing

According to Keefe (2004) "Marketing and organizational functions of processes for creating, communicating, and delivering value to customers and for managing customer relationships in ways that benefit the organization and its stakeholders" (Jamrozy, 2007). While the marketing goal is to identify customer needs and meet those needs well, so that all products sell themselves.

Hadžić (2005) said that "Marketing in tourism is a management process of anticipating and fulfilling the wishes and potential tourists, guided by profitable goals or goals of the community or both" (Kosic et al., 2010; Rebollo, 2018). The main purpose of destination marketing must be to direct the optimization of the impact of tourism and maximize benefits for the region.

According to Williams (2006) "The key reason for this is up to recently marketing for tourism services has been focused not on the consumer, but the destination or outlet, with marketing strategies being related to the products offered."

Tourism marketing further emphasizes who is actually a market segment and how it behaves (Damanik, 2006). Marketing tourism according to (Holloway \& Robinson, 1995) consists of 7 P, namely product, positioning, price, promotion, place, packaging, partnership.

The most important thing in tourism marketing is to bring each partner to work together rather than compete to attract resources towards the development of an integrated marketing mix and shipping system. The tourism strategy should not only focus on visits, but also cover all impacts such as population density, congestion, environmental pollution, safety and security, seasonal adjustment problems, sensitivity to local culture (Evans et al., 1995; Sinh et al., 2016). Riege \& Perry (2000) have proposed three strategic approaches that can be used in the tourism industry, namely:

1. The consumer-oriented approach refers to the use of a differentiated (target marketing) or undifferentiated marketing strategy depending on market conditions

2. The competitor-oriented approach focuses on competition where the role of marketing is to develop, maintain or defend the position of a tourism organization

3. The trade-oriented approach focuses on intermediaries and it might be more relevant to the travel and tourism industry

Players in Marketing Tourism

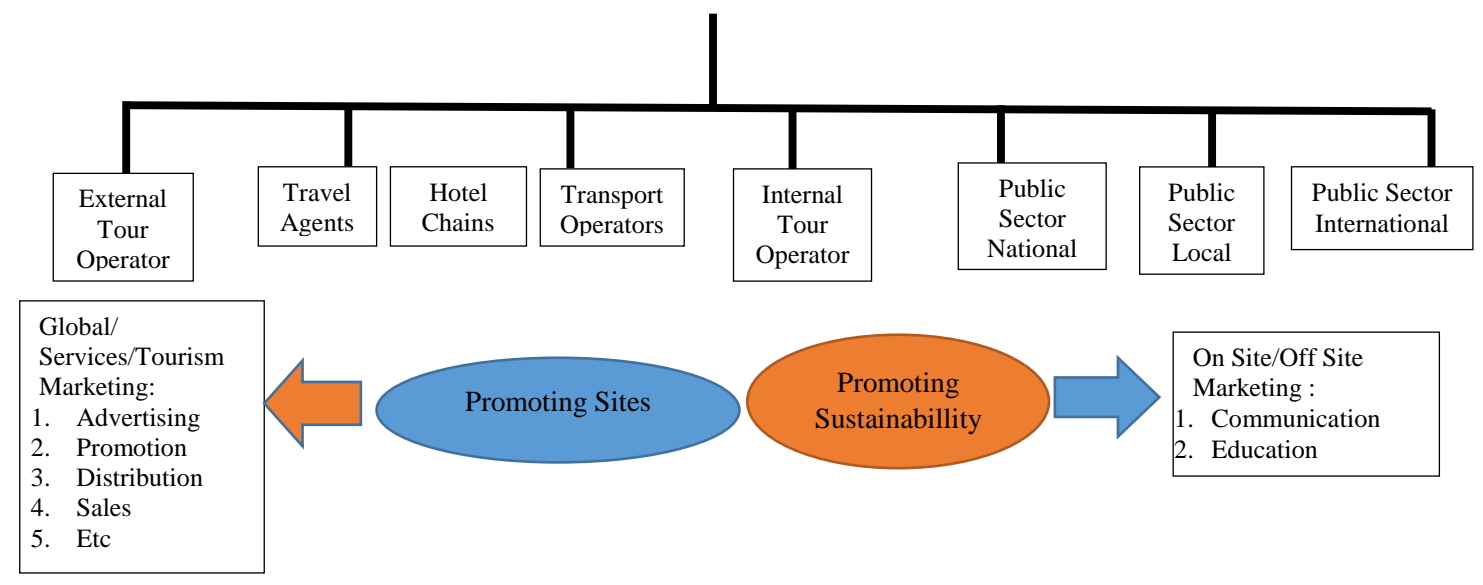

Fig. 1. Tourism marketing imbalances 
These promotional activities, both the private and public sectors, are mostly off-site marketing promotions. The picture above illustrates players in tourism infrastructure (above) and marketing activities (left side) used to attract a number of tourists (Carson et al., 2004).

"To manage and market sustainable tourism, both the promotion of the sites as a tourist attraction and managing the economic, social, and environmental sustainability of the sites are vitally important" (Klemm, 1992; Sharpley, 2002; Smith \& Eadington, 1992; Silva \& Madushani, 2017; Thorsell \& Sigaty, 2001).

The dimensions that will be used to measure tourism marketing refer to several dimensions that have been used in previous studies (Jamrozy, 2007; Tsiotsou et al., 2010; Yoon \& Uysal, 2005).

Tourism marketing dimensions are :

\section{Economy}

2. Social

3. Culture

4. InformationTechnology

5. Environment

Intention to visit

Soderlund \& Ohman (2003) defines intention as the basic unit that arises when individuals designate future-oriented cognitive activities such as mental stimulation, planning, imagination, and thinking (such as indi- vidual perceptions of other people's intentions, according to Susanto \& Kotler (2000) strong internal stimuli that motivates action (statement of interest to revisit), where this drive is influenced by stimulus and positive feelings about the product.

Intention to visit can be defined as a potential plan for visiting a destination (Chen \& Tsai, 2007; Kaplanidou \& Vogt, 2007; Ng et al., 2007). "Among behavioral intentions, in particular, intention to (re)visit or travel is one of the most significant dependent variables, as it could directly explain the possibility that a potential visitor may visit" (Ng et al., 2007).

The dimensions of interest in visiting include the following (Schifman \& Kanuk, 2007) :

- Interest

- Searching Information

- Preference

Destination Management Organizations (DMO) addresses four main generic strategic goals to ensure the level of satisfaction and tourists, namely:

Strategic management and marketing objectives for destinations

- Enhance the long-term prosperity of local people

- Delight visitors by maximizing their satisfaction

- Maximize profitability of local enterprises and maximize multiplier effects

- Optimize tourism impacts by ensuring a sustainable balance between economic benefits and socio-cultural and environmental costs

\begin{tabular}{|l|}
\hline \multicolumn{1}{|c|}{ Strategic Management and Marketing Objectives for Destinations } \\
\hline - \\
Enhance the long-term prosperity of local people \\
- Delight visitors by maximizing their satisfaction \\
- Optimize tourism impacts by ensuring a sustainable balance between economic benefits and \\
socio-cultural and environmental costs
\end{tabular}

Fig. 2. Strategic management and marketing objectives for destinations

\section{Decision to visit}

Visiting decision theory is analogous to buying decisions, such as research conducted by Jalilvand \& Samiei (2012) which equates that tourist visiting decisions are the same as consumer purchasing decisions (Aprilia, 2015).

Hollensen (2010) states that the influence of consumer decision making has the same business as other consumers. Some important things namely Psychological variables that become influences in consumer decision making include needs, perception, memory and attitudes.

Review of the relevant literature related to each of the selected research streams: a) Destination beliefs, resulting from the cognitive judgments that individuals integrate within their holistic impressions of the destination Chen \& Tsai (2007); b) event satisfaction, defined as the overall enjoyment experienced by the visitor, resulting from the event's ability to meet customer expectations and needs (Baker \& Crompton, 2000); c) tourist push motivation, depicted as internal forces, coming from an unsatisfied need that pushes the individual to become involved in a specific tourism experience (Meng et al., 2008; Yoon \& Uysal, 2005); d) attitudes toward the event, measured both in terms of event loyalty and of positive word of mouth (Kaplanidou \& Vogt, 2007); e) product receptivity, defined as the conscious or unconscious readiness to buy products coming from an area which is different from the visitor's territory of origin (Dhar \& Kim, 2007).

\section{Methodology}

This research is quantitative research with its testing using the Partial Least Square (PLS) method and SEM analysis. SEM is a statistical technique that is able to analyze the pattern of relationships between latent constructs and indicators, latent constructs with each other, and measurement errors directly. SEM allows direct analysis between several dependent and independent variables (Hair et al., 2014).

Data collection was carried out in several leading tourist objects in the City of Bandung and Soppeng with the number of respondents 100 respondents from tourists in the city of Bandung, as well as 100 respondents who were tourists in Soppeng Regency.

Respondent data retrieval is done randomly by the random method sampling, i.e. the respondent is a tourist visiting Bandung and Soppeng. The number of samples is in accordance with the minimum requirement of 30 (Sugiyono, 2017) with an error term rate of $90 \%$.

This questionnaire uses a Likert scale from 1 to 5 ( 1 strongly disagrees; 2 disagrees; 3 quite agrees; 4 agrees; 5 strongly agrees) Sugiyono (2017).

The limitation of the research is only in the areas of Bandung and Soppeng and only examine the application of the model in both regions. 


\section{Results and Discussion}

PLS Model for marketing tourism, intention to visit, and decision to visit Bandung

Testing the hypothesis in this study using the PLS method. PLS is an alternative method of analysis with variance-based SEM. The advantage of this method is that it does not require assumptions and can be estimated with a relatively small number of samples. The tool used is a SmartPLS Version 2 program specifically designed to estimate structural equations on the basis of variance. The structural model in this study is shown in Figure 3 below.

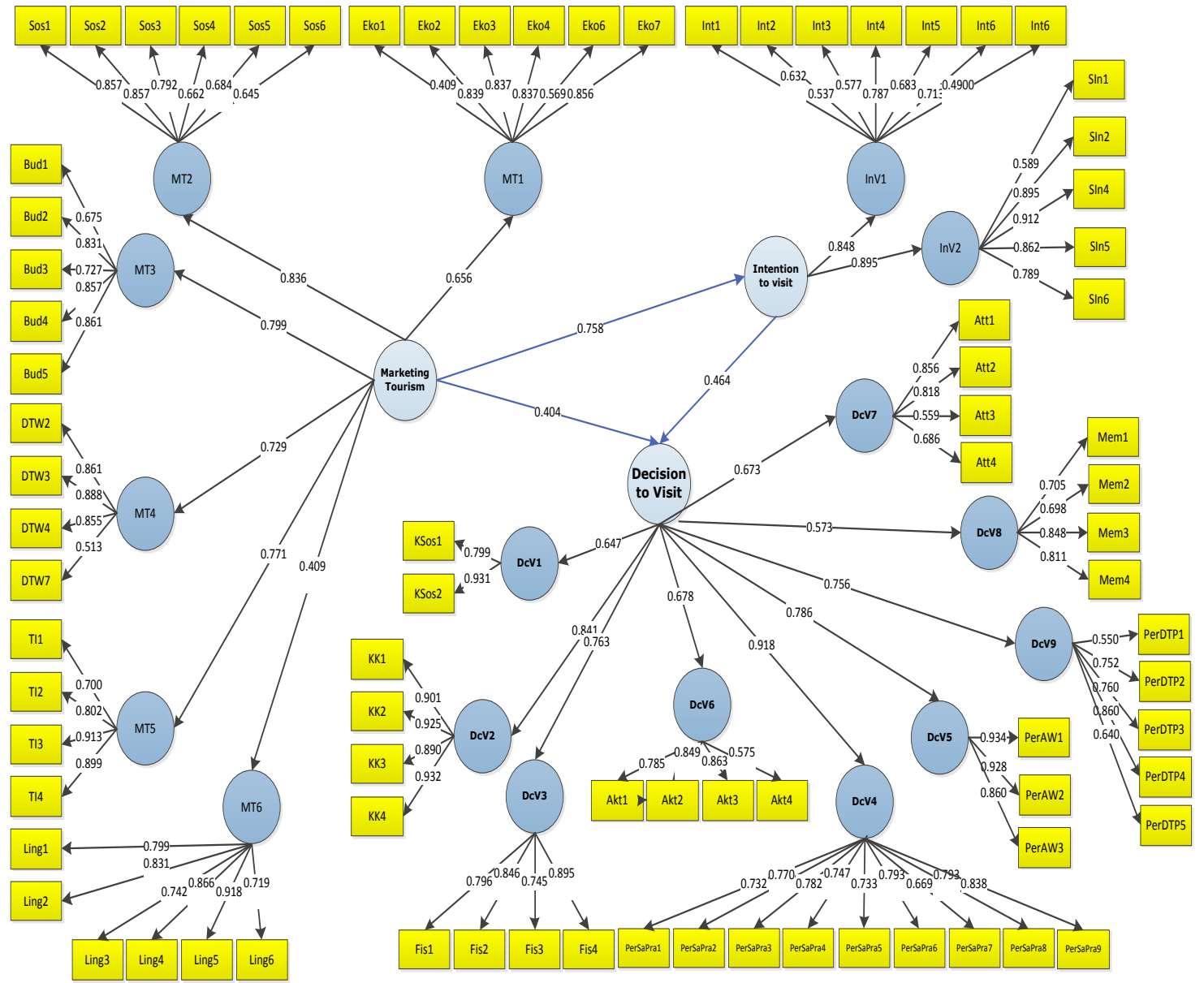

Fig. 3. Inner and outer model

The figure shows that the marketing tourism construct was measured with 6 dimensions (MT1-MT6) with a total number of indicators 35. Likewise the intention to visit construct was measured in 2 dimensions (Inv1 and InV2) with a total of 13 indicators, and the decision to visit construct was measured by 9 dimensions (DcV1-DcV9) with a total of 41 indicators. The direction of the arrow between indicators with latent constructs is towards indicators that show that research uses reflective indicators that are relatively appropriate for measuring perceptions. The relationship to be examined (hypothesis) is symbolized by an arrow between constructs.

\section{Structural model testing (Inner model)}

Analysis of the structural model (inner model) shows the relationship between latent variables. This test is shown by the value of on endogenous constructs. The value of $R^{2}$ is the coefficient of determination in endogenous constructs. The assessment range of $R^{2}$ according to Chin (1998) is: the value of $R^{2}$ of 0.67 (strong), 0.33 (moderate) and 0.19 (weak). After the estimated model meets the Outer Model criteria, then the structural model is tested. construct:

Table IV

R-Square

\begin{tabular}{ll}
\hline Variable & $R^{2}$ \\
\hline Decision to Visit & 0.662 \\
Intention to visit & 0.574 \\
Marketing Tourism & - \\
\hline
\end{tabular}

The table above gives a value of 0.662 for the construct of decision to visit, which means that marketing tourism is able to explain the variance (affect) of decision to visit by $66.2 \%$. The R-square value is also found in intention to visit which is influenced by Tourism Marketing of 0.574 . The table above gives the value $R^{2}$ on the criteria that are close to strong, so it can be concluded that the research model is supported by empirical conditions or fit model. Testing the hypothesis for the path coefficient second order is as follows: 
Table V

Test hypothesis Of path coefficients

\begin{tabular}{|c|c|c|c|c|c|}
\hline Hypothesis & Coef. of Estimation & Standard Error of Estimation (STERR) & $t$ Statistics & $R^{2}$ & Explanation \\
\hline Marketing Tourism $\rightarrow$ Intention to visit & 0.758 & 0.060 & 12.559 & 0.574 & Significant \\
\hline Marketing Tourism $\rightarrow$ Decision to Visit & 0.404 & 0.082 & 4.927 & 0.163 & Significant \\
\hline Intention to visit $\rightarrow$ Decision to Visit & 0.464 & 0.088 & 5.275 & 0.215 & Significant \\
\hline
\end{tabular}

The table above shows that the value of $t$ count for all paths (path coefficient) shows a value greater than $t$ table $(=1.96)$ which means that the influence between significant constructs.

PLS model for marketing tourism, intention to visit, and decision to visit Soppeng

Testing the hypothesis in this study using the PLS method. PLS is an alternative method of analysis with variance-based SEM. The advantage of this method is that it does not require assumptions and can be estimated with a relatively small number of samples. The tool used is a SmartPLS Version 2 program specifically designed to estimate structural equations on the basis of variance. The structural model in this study is shown in Figure 4 below.



Fig. 4. Inner and outer model

The figure shows that the construct of marketing tourism is measured by 6 dimensions (MT1-MT6). Likewise, the Intenton to Visit construct is measured in 2 dimensions (Inv1 and InV2), and the Decision to Visit construct is measured in 9 dimensions (DcV1-DcV9). The direction of the arrow between indicators with latent constructs is towards indicators that show that research uses reflective indicators that are relatively appropriate for measuring perceptions. The relationship to be examined (hypothesis) is symbolized by an arrow between constructs.

\section{Structural model testing (Inner model)}

Analysis of structural model (inner model) shows the relationship between latent variables. This test is shown by the value of $R^{2}$ on endogenous constructs. The value of $R^{2}$ is the coefficient of determination in endogenous constructs. The assessment range of $R^{2}$ according to Chin (1998), is: the value of $R^{2}$ of 0.67 (strong), 0.33 (moderate) and 0.19 (weak). After the estimated model meets the Outer Model criteria, then the structural model is tested. construct: 
Table VI

R-Square

\begin{tabular}{ll}
\hline Variable & $R^{2}$ \\
\hline Decision to Visit & 0.733 \\
Intention to visit & 0.709 \\
Marketing Tourism & - \\
\hline
\end{tabular}

The table above gives high values for the decision to visit construct. The R-square value is also found in intention to visit which is influenced by Tourism Marketing of 0.709 . The table above gives the value $R^{2}$ on the criteria that are close to strong, so it can be concluded that the research model is supported by empirical conditions or fit model. Testing the hypothesis for the path coefficient second order is as follows:

Table VII

Test hypothesis Of path coefficients

\begin{tabular}{|c|c|c|c|c|c|}
\hline Hypothesis & Coef. of Estimation & Standard Error of Estimation (STERR) & $t$ Statistics & $R^{2}$ & Explanation \\
\hline Marketing Tourism $\rightarrow$ Intention to Visit & 0.842 & 0.025 & 34.207 & 0.709 & Significant \\
\hline Marketing Tourism $\rightarrow$ Decision to Visit & 0.327 & 0.097 & 3.353 & 0.107 & Significant \\
\hline Intention to Visit $\rightarrow$ Decision to Visit & 0.563 & 0.097 & 5.786 & 0.317 & Significant \\
\hline
\end{tabular}

The table above shows that the value of $t$ count for all paths (path coefficient) shows a value greater than $t$ table $(=1.96)$ which means that the influence between significant constructs.

The results of the research support several studies that have been carried out such as destination beliefs, event satisfaction and post-visit product receptivity in event marketing as well as results from a tourism experience (Chang et al., 2017; Mainolfi, 2018) and influence of movies and television on Chinese tourists perception toward international tourism destinations (Wen et al., 2018), so that the application of the model will be different when it is done in other regions. And it needs to examine the model in depth in each of its variables.

\section{Limitations and Future Research Directions}

The current study has proposed a model which is open for further exploration and testing. The applicability of the proposed model is limited to Indonesian region only. However, it must be applied and tested in other regions as it is anticipated that the application of the model will be different in different regions. Specifically, researchers are encouraged to test this model in Europe and identify if the applications are same across western and eastern regions.

\section{Conclusion}

In the PLS Model for marketing tourism, intention to visit, and decision to visit, which were tested in 2 places, leading attractions in Bandung and Soppeng can be seen in the results; both showed significant influence between constructs. This means that the tested construct has a major effect on the development of tourism in both.

For this reason, the government must focus more on developing tourism using this model so that it will cause tourists to be more interested and more interested in visiting. It is expected that tourists not only come once but repeatedly.

\section{References}

Aprilia, F. (2015). Effect of word of mouth on visiting interests and their impact on visiting decisions (Survey of visitors to the "Jawa Timur Park 2 " tourist attraction in Batu city). Journal of Business Administration, 24(1), 1-6.

Baker, D. A., \& Crompton, J. L. (2000). Quality, satisfaction and behavioral intentions. Annals of Tourism Research, 27(3), 785-804. doi:https://doi.org/10.1016/S0160-7383(99)00108-5
Carson, D., Gilmore, A., Ascenção, M. P., \& Fawcett, L. (2004). Holistic tourist industry marketing: Significant deficiencies in relation to natural tourist sites. Journal of Marketing Theory and Practice, 12(4), 49-59. doi:https://doi.org/10.1080/10696679.2004.11658532

Chang, T. C., Wu, S. F., Hsu, S. C., \& Yang, C. C. (2017). A study of the tourism industry in East Taiwan. Journal of Advanced Research in Social Sciences and Humanities, 2(1), 61-66. doi:https://doi.org/10.26500/jarssh02-2017-0108

Chen, C.-F., \& Tsai, D. (2007). How destination image and evaluative factors affect behavioral intentions? Tourism Management, 28(4), 1115-1122. doi:https://doi.org/10.1016/j.tourman.2006.07.007

Chin, W. W. (1998). The partial least squares approach to structural equation modeling. Modern Methods for Business Research, 295(2), 295-336.

Damanik. (2006). Ecotourism planning from theory to application. Yogyakarta, Indonesia: Andi Offset.

Dhar, R., \& Kim, E. Y. (2007). Seeing the forest or the trees: Implications of construal level theory for consumer choice. Journal of Consumer Psychology, 17(2), 96-100. doi:https://doi.org/10.1016/S1057-7408(07)70014-1

Evans, M. R., Fox, J. B., \& Johnson, R. B. (1995). Identifying competitive strategies for successful tourism destination development. Journal of Hospitality \& Leisure Marketing, 3(1), 37-45. doi:https://doi.org/10.1300/J150v03n01_04

Hadžić, O. (2005). Cultural tourism (Unpublished master's thesis). Faculty of Science, Department of Geography, Tourism and Hotel Management, Novi Sad, Serbia.

Hair, J. F., Gabriel, M., \& Patel, V. (2014). AMOS Covariance-Based Structural Equation Modeling (CB-SEM): Guidelines on its application as a marketing research tool. Brazilian Journal of Marketing, 13(2), 44-55. doi:https://doi.org/10.5585/remark.v13i2.2718

Hollensen, S. (2010). Marketing management: A relationship approach. London, UK: Pearson Education.

Holloway, J. C., \& Robinson, C. (1995). Marketing for tourism. Harlow, England: Longman.

Jalilvand, M. R., \& Samiei, N. (2012). The impact of electronic word of mouth on a tourism destination choice: Testing the theory of planned behavior (TPB). Internet Research: Electronic Networking Applications and Policy, 22(5), 591-612. doi:https://doi.org/10.1108/10662241211271563 
Jamrozy, U. (2007). Marketing of tourism: A paradigm shift toward sustainability. International Journal of Culture, Tourism and Hospitality Research, 1(2), 117-130. doi:https://doi.org/10.1108/17506180710751669

Kaplanidou, K., \& Vogt, C. (2007). Path analysis of sport event image influence on spectator's intentions to revisit the hosting destination. In North American Society for Sport Management Conference (p. 379-380). Florida, FL.

Keefe, L. M. (2004). What is the meaning of 'marketing'? Marketing News, $38(15), 17-18$

Klemm, M. (1992). Sustainable tourism development: Languedoc-Roussillon thirty years on. Tourism Management, 13(2), 169-180. doi:https://doi.org/10.1016/0261-5177(92)90059-G

Kosic, K., Lazic, L., \& Stojanovic, V. (2010). Application of contemporary marketing destinations-Case study of Vojvodina. Tourism and Hospitality Research, 16(1), 427-436.

Mainolfi, G. (2018). To have is to be! Bandwagon effect, consumer ethnocentrism and intentions to buy foreign luxury products online. A survey of Chinese consumers. In 2018 Global Marketing Conference at Tokyo (p. 623-623). Japan.

Meng, F., Tepanon, Y., \& Uysal, M. (2008). Measuring tourist satisfaction by attribute and motivation: The case of a nature-based resort. Journal of Vacation Marketing, 14(1), 41-56.

Ng, S. I., Lee, J. A., \& Soutar, G. N. (2007). Tourists' intention to visit a country: The impact of cultural distance. Tourism Management, 28(6), 1497-1506. doi:https://doi.org/10.1016/j.tourman.2006.11.005

Rebollo, H. P. M. (2018). A structural model of millennial tourist behavior towards tourism in Davao region. Journal of Advances in Humanities and Social Sciences, 4(1), 26-36. doi:https://doi.org/10.20474/jahss-4.1.3

Riege, A. M., \& Perry, C. (2000). National marketing strategies in international travel and tourism. European Journal of Marketing, 34(11), 1290-1305. doi:https://doi.org/10.1108/03090560010348452

Schifman, L., \& Kanuk, L. (2007). Consumer behaviour. Upper Saddle River, NJ: Prentice Hall International.

Sharpley, R. (2002). Rural tourism and the challenge of tourism diversification: The case of Cyprus. Tourism Management, 23(3), 233-244. doi:https://doi.org/10.1016/S0261-5177(01)00078-4
Silva, H., \& Madushani, R. (2017). The impact of human resource competencies of front line employees on tourist arrivals of unclassified hotels in western province, Sri Lanka. Journal of Advanced Research in Social Sciences and Humanities, 2(1), 09-16. doi:https://doi.org/10.26500/jarssh-02-2017-0102

Sinh, B. D., Nga, V. T., Linh, V. T. H., \& Tuan, N. H. (2016). Stakeholder model application in tourism development in Cat Tien, Lam Dong. Journal of Advanced Research in Social Sciences and Humanities, 1(1), 73-95. doi:https://doi.org/10.26500/jarssh-01-2016-0110

Smith, V. L., \& Eadington, W. R. (1992). Tourism alternatives: Potentials and problems in the development of tourism. Philadelphia, Pennsylvania: University of Pennsylvania Press.

Soderlund, M., \& Ohman, N. (2003). Behavioral intentions in satisfaction research revisited. Journal of Consumer Satisfaction, Dissatisfaction and Complaining Behavior, 16, 53-66.

Sugiyono. (2017). Quantitative, qualitative, and $R \& D$ research methods. Bandung, Indonesia: Afabeta.

Susanto, A., \& Kotler, P. (2000). Marketing management in Indonesia. Jakarta, Indonesia: Salemba.

Thorsell, J., \& Sigaty, T. (2001). Human use in World Heritage natural sites: A global inventory. Tourism Recreation Research, 26(1), 85-101. doi:https://doi.org/10.1080/02508281.2001.11081181

Tribun-Timur. (2017). Sopeng: Travel. Retrieved from https://bit.ly/ $34 \mathrm{r} 42 \mathrm{qL}$

Tsiotsou, R. H., Ratten, V., \& Tsiotsou, R. (2010). Future research directions in tourism marketing. Marketing Intelligence \& Planning, 28(4), 533-544. doi:https://doi.org/10.1108/02634501011053702

Wen, H., Josiam, B. M., Spears, D. L., \& Yang, Y. (2018). Influence of movies and television on chinese tourists perception toward international tourism destinations. Tourism Management Perspectives, 28, 211-219. doi:https://doi.org/10.1016/j.tmp.2018

Williams, A. (2006). Tourism and hospitality marketing: Fantasy, feeling and fun. International Journal of Contemporary Hospitality Management, 18(6), 482-495. doi:https://doi.org/10.1108/09596110610681520

Yoon, Y., \& Uysal, M. (2005). An examination of the effects of motivation and satisfaction on destination loyalty: A structural model. Tourism Management, 26(1), 45-56. doi:https://doi.org/10.1016/j.tourman.2003.08.016 